\title{
Emergency Remote Teaching Amidst Global Pandemic: Voices of Indonesian EFL Teachers
}

\author{
Arif Nugroho' $^{1}$, Mariam Haghegh ${ }^{2}$, Yunika Triana ${ }^{3}$
}

IAIN Surakarta, Indonesia ${ }^{1} \& 3$

Eastern Mediterranean University North Cyprus, Turkey ${ }^{2}$

Correspondence: Arif Nugroho, IAIN Surakarta Indonesia, email: arif.nugroho@iain-surakarta.ac.id

Submitted: March 18, $2021 \quad$ Revised: April 22, $2021 \quad$ Accepted: April 23, 2021

DOI: 10.29408/veles.v5i1.3258 URL: http://dx.doi.org/10.29408/veles.v5i1.3258

\begin{abstract}
A number of studies have been conducted to examine the practices and challenges of online English language teaching in the age of Covid-19 pandemic. However, research on the teachers' insights and suggestions to overcome the challenges of the emergency remote teaching still remains unexplored. The present study shed some light on EFL teachers' teaching activities, challenges, and insights of the emergency remote teaching amidst the global pandemic. The data were obtained from 27 Indonesian EFL teachers (17 female and 10 male) by means of self-written reflection and semi-structured interview. The results revealed that the emergency remote teaching activities were conducted by administering online forum and discussion, integrating social media, and designing interactive exercises. Notwithstanding the facts, the teachers encountered some challenges such as unfamiliarity with digital platforms, inability to provide quick feedbacks, and lack of students' motivation and engagement during the remote teaching. In responding to the challenges, this study further depicted that joining professional development programs, creating representative lesson plan, and designing interactive online classroom activities could become alternative solution. These results contribute to the realm of English language teaching as fruitful insights and as a 'wake-up call' for educational stakeholders in order to enhance the efficacy of online teaching and learning, particularly during the global pandemic.
\end{abstract}

Keyword: Emergency Remote Teaching, ELT in Global Pandemic, Indonesian EFL Teachers

\section{Introduction}

The current situation of global pandemic as a result of Coronavirus disease 2019 (Covid-19) outbreak has significantly altered how people behave in their daily life. All countries around the world that have been affected by this contagious disease require their society to do social and physical distancing in order to avoid infection. Social distancing measure is a control action and behavioral changes by minimizing contact rates between susceptible individuals and infected individuals who may transmit the disease to avoid infectious transmission (Reluga, 2010). In the case of Indonesia, the global pandemic has affected social interaction among people, including the 
implementation of teaching and learning activities. Consequently, the activities of face-to-face learning interaction in a formal classroom shift to informal online learning outside classroom using a range of available digital learning platforms, including English language teaching and learning.

The sudden change of formal interaction inside classroom into informal digital learning beyond classroom obviously leads to several consequences. First, it surprises not only teachers and students but also school administrators and authorities since the situation of global pandemic has not been forecasted previously (Amin \& Sundari, 2020). Second, teachers and students have to adapt to the emergency online teaching and learning in order to maintain the efficacy of language learning as it is conducted in face-to-face classroom interaction (Abdulkareem \& Eidan, 2020). Third, shifting from face-to-face classroom interaction to online teaching and learning brings a number of challenges, advantages, and disadvantages both for teachers and students (Ivone et al., 2020; Satar, 2018). Hence, at this case, the attitude and perception of teachers and students toward the practice of emergency remote teaching and learning become a crucial matter in order to conduct successful online learning activities.

With the advanced development of technology in this twenty-first century teaching, the use of digital platforms such as applications, learning management system, and social networking sites in an English teaching and learning is not new. Today's language learning has extensively integrated a variety of digital tools, social media, and virtual environments to enhance the efficacy of teaching and learning (Lam et al., 2018; Nugroho \& Mutiaraningrum, 2020). As a result, teachers must be aware of digital device use for their classroom since it has a significant impact on language learners' development (Chun et al., 2016; Hembrough \& Jordan, 2020; Lam et al., 2018). Nevertheless, the current teaching and learning situation does not look like regular teaching activities, nor does it seem to be well-planned online classroom instructions. Teachers and students are required to encounter a critical teaching and learning situation with lack of sources in a hurry. Mutiaraningrum and Nugroho (2020) considers the present situation as Emergency Remote Teaching and Learning to portray the shifting of formal instructional classroom to alternate online learning because of crisis circumstances. Considering the closures of educational institutions as a result of the global pandemic in Indonesia, the sudden alteration from face-to-face classroom interaction to online learning beyond classroom can be classified as an Emergency Remote Teaching.

Recently, the issue of English language teaching in the age of Covid-19 pandemic has attracted scholars' attention; therefore, its implementation and practices have extensively been studied. Atmojo and Nugroho (2020) examined the teaching activities and challenges during Covid-19 pandemic in Indonesian English language teaching context. By involving 16 secondary EFL teachers, the results depicted that the teachers conducted online teaching and learning in a variety of activities ranging from checking the students' attendances to synchronously or asynchronously examining the students' works. Several digital platforms such as learning management system and messenger applications were used to carry out the emergency remote teaching. Notwithstanding the facts, both teachers and students were found to encounter some challenges during the online teaching such as lack of motivation, lack of creative teaching 
methods, limited internet access, and difficulty in designing appropriate materials. This study suggests that future prospective inquiries are strongly encouraged to find out the applicable solutions as an effort to enhance the efficacy of this emergency remote learning.

In Malaysian context, Krishan et al. (2020) made use of an explanatory mixed method to shed some light on learners' perception toward learning English through free online resources during Covid-19 pandemic. Drawing on the data obtained from twenty-five international preelementary English students, it was found that the learners considered free online resources as beneficial tools to enhance language skills such as reading, conversation, and vocabulary. Unlike Atmojo and Nugroho's (2020) study, this study does not depict challenges and problems encountered by both teachers and students in conducting the emergency remote learning. In the contrary, this study further showed that the learners had constructive attitudes toward the online learning resources. This study also indicated that the online teaching environments could enhance the learners' critical and analytical thinking skills and motivated mutual interaction between students and teachers, students and their friends, and other participants.

In the case of Ghana, Agormedah et al. (2020) explored the English learners' attitudes toward emergency online learning in higher education. A descriptive survey using online questionnaire was employed to gather the required data from 467 students of higher education institutions in Ghana. Similar to the results of Krishan et al. (2020), the study revealed that the learners positively responded to the online learning. Several digital platforms were preferred by the learners, i.e. UCC Moodle, Alison, Google classroom, and social media. However, the study also found several challenges that the students were lack of formal orientation and training, perceived limited access of internet connectivity, and experienced financial unpreparedness, which were similar to the results reported by Atmojo and Nugroho (2020). This study recommends that an immense project should be conducted by future researchers to seek for the best solutions to create an effective online classroom activities, particularly in the age of emergency remote teaching and learning.

A study conducted in Pakistani English language teaching context by Adnan and Anwar (2020) investigated the perception of higher education students towards the practice of compulsory courses that were conducted online in the age of Covid-19. Using an online survey, the findings highlighted a surprising conclusion that online teaching and learning could not produce desired results in underdeveloped country like Pakistan. The most possible reason as stated in the study was the majority of Pakistani students were unable to access internet connectivity due to technical as well as monetary issues. In contrast to the study of Krishan et al. (2020), the results of this study suggested that educational organizations have to rearrange their curriculum and design proper materials for online lectures.

In a similar direction, Abdulkareem and Eidan (2020) reported the practice of online learning for higher education continuity in Iraq during Covid-19 pandemic. The study revealed that English language teaching in Iraq was conducted by means of some digital platforms such as Google classroom and Zoom video conference. However, similar to the results reported by Agormedah et al. (2020), Atmojo and Nugroho (2020), and Krishan et al. (2020), the online learning system in higher education in Iraq was found to face a number of disadvantages such as limited experiences 
and trainings to perform the technological learning mission, uninterrupted internet in many regions and electrical power outage, as well as the teachers and students' unfamiliarity of digital learning devices. This study suggests that face-to-face classroom interactions were more preferred by both teachers and students in Iraq instead of online learning beyond classroom.

Having explored the current studies conducted around the world about the issue of English language teaching in the age of Covid-19 pandemic, two research gaps are observable. First, the above-mentioned previous research have mainly concerned with examining how emergency online teaching and learning was conducted as well as challenges that teachers and students encountered during the online learning. Thus, teachers' insights and suggestions to overcome the challenges still remain unexplored. To date, to the best of the authors' knowledge, EFL teachers' suggestions towards emergency remote learning during Covid-19 pandemic have not been investigated, particularly in Indonesian English language teaching context. Examining teachers' insights and suggestions in the current situation is crucial to develop the efficacy of online teaching practices in the age of this global pandemic. Second, most of the previous literature focused their inquiries on the students' perspectives towards the practice of online teaching and learning (Abdulkareem \& Eidan, 2020; Adnan \& Anwar, 2020; Agomerdah et al., 2020; Krishan et al., 2020), while there was only the study of Atmojo and Nugroho (2020) that spotlighted the teachers' point of views about online teaching amidst the global pandemic. Hence, more studies on the teachers' perspectives should be conducted to provide empirical evidences and contribute to the literature enrichment.

As an attempt to close the observable research gaps, the present study examines how Indonesian EFL teachers conduct the emergency remote teaching, deal with its challenges and problems, and propose their insights and suggestions to overcome the barriers. This study differs from the previous research since it not only concerns with teaching activities and challenges, but it also investigates teachers' insights to overcome the challenges, which is absence in the previous studies. What else puts this study distinct to others is that the use of self-written reflection as the instrument that enables the researcher to collect rich and in-depth data on the participants perceptions towards teaching activities, challenges, and insights of emergency remote teaching, in which most of the previous studies mainly made use of online survey questionnaire. To ensure the objectives, this study is guided under three research questions: (1) how do Indonesian EFL teachers carry out teaching activities during emergency remote teaching? (2) what challenges do Indonesian EFL teachers encounter during emergency remote teaching? and (3) what insights and suggestions do Indonesian EFL teachers offer to overcome the challenges of emergency remote teaching?

\section{Method}

\subsection{Rationale of the Method}

The present study aims to delineate how Indonesian EFL teachers carry out learning activities during emergency remote teaching, what challenges they encounter, and what insights and suggestions they offer to overcome the challenges. To reach the objectives, this study made use of descriptive approach by employing self-written reflection and semi-structured interview. 
The research approach enables the authors to portray, depict, and describe an in-depth understanding of the EFL teachers about the phenomenon being studied, i.e. emergency remote teaching (Hollweck, 2015; Yin, 2015). In the present study context, the way the EFL teachers conduct teaching activities, the challenges they encounter, and the insights they provide were accurately portrayed by following this approach.

\subsection{Research Context and Participants}

The in-hand study was conducted in the context of Indonesian English language teaching in secondary level, where English is considered as a foreign language. By this context, an English language classroom becomes the most available place for learners to obtain language exposures. This study involved 27 Indonesian EFL teachers (17 females, 10 males, namely P1-P27) teaching at secondary schools around Central Java province Indonesia. The participants were voluntarily participated upon invitation and purposively selected based on two primary criteria, i.e. (1) teaching English using digital technology in the emergency remote teaching during the global pandemic and (2) having experiences in teaching English at secondary level at least for three years. The age of the participants was varied between 24 and 40, with the average age of 29. In terms of education qualification, 21 (77.8\%) teachers earned undergraduate degree in English education and linguistic studies and the rest $(6,22 \%)$ had a master degree in English language teaching.

\subsection{Instruments and Data Collection}

Self-written reflection and semi-structured interview were employed in this study to gather the required data. Self-written reflection was firstly used to seek for the empirical answers of the three research questions. According to Barkhuizen (2014), it is a writing story template consisting of several questions that reflect the main problems and/or objectives of the study. The participants were to express their responses in the provided blank spaces based on the experiences related to emergency remote teaching by answering five questions employed in this study (see appendix). This instrument was administered to the participants from May to September 2020 when teaching online was the only possible alternative to conduct teaching and learning activities. Because of the pandemic situation, it was distributed online using Google form in which its link was delivered through WhatsApp, the most frequently used messenger application of Indonesian. The questions of self-written reflection were in English; however, the participants were notified that they were free to answer the questions in English or Indonesia, depending on their preferences. The main benefit of this data collection tool was that the participants could freely write intelligible responses to the questions based on their thoughts and experiences, so that an in-depth and rich description about the phenomena being studied could be clearly depicted (Dörnyei, 2014).

Following self-written reflection, semi-structured interview was conducted to 6 selected participants, namely P3, P11, P13, P19, P20, and P25. They were invited to provide follow up and more detailed explanation about their fascinating experiences and stories as well as their online teaching challenges as expressed in the self-written reflection, so that they were worthy of more in-depth exploration. The semi-structured interview last for about 30 minutes each participant and conducted by means of telephone call. Similar to the self-written reflection, the semi-structured interview was conducted in Indonesian and English, depending on the participants' preferences. 
The main benefit of this data collection instrument is that it enables the interviewer to come up with new ideas and questions during the conversation (Harding, 2018). In other words, the interviewer has a guidance in hands but it is still possible to extend the interview when a new issue appears. The semi-structured interview was recorded and transcribed as a basis of data analysis. To maintain the validity, the interviewer, who was also the researcher, took notes during the conversation. Ethical consent and approval were obtained from the participants before administering data collection.

\subsection{Data Analysis}

The data obtained from self-written reflection and semi-structured interview were analyzed by adapting sequential explanatory procedures (Creswel, 2009). First, the data from self-written reflection were analyzed then followed by the semi-structured interview data. Second, the researcher classified the data based on important themes as reflected in the research questions, i.e. teaching activities, challenges, and insights of emergency remote teaching. Third, the researcher coded, reviewed, analyzed, and integrated the emerging themes that lead to the final results of data analysis and further used (missing object) as a basis of conclusion drawing. To ensure the trustworthiness, the author invited two examiners in the field of English language teaching to individually perform the procedures of data analysis. Finally, several stages of discussion were conducted to achieve the consensus on the final results.

\section{Results and Discussion}

This section presents the results of data analysis with regards to how Indonesian EFL teachers conduct teaching activities during Covid-19 pandemic, what challenges they encounter, and insights and suggestions they offer to overcome the challenges. The most representative excerpts of the participants' responses both from self-written reflection and semi-structured interview are presented to support the delineation of the findings. Most of the excerpts were original from the participants' utterances, but in some responses the researchers did alteration in terms of grammar efficacy without altering the substance. In the presentation of the excerpts, "WR" is used as code for data from self-written reflection, while "Int" is employed as code for semi-structured interview data.

\subsection{Results}

\subsubsection{Emergency Remote Teaching Activities amidst Global Pandemic}

The results of data analysis depicted various online teaching activities performed by Indonesian EFL teachers. First, online forum and discussion became familiar as an alternative of virtual learning activities since the establishment of emergency remote teaching during the global pandemic. Most of the participants conducted a synchronous online forum and discussion using available digital platforms such as video conferences, learning management system, and messenger applications.

"For me, online teaching and learning does not decrease my motivation to design interactive teaching activities. One of the ways is conducting online forum where we can discuss and conduct teaching activities as if in the real classroom. I often use Google meet as an online platform to conduct my speaking activities with my students. In addition, I also make use of 
WhatsApp group to conduct online discussion, mostly when we practice writing and grammar exercises." (WR. P7)

"In the age of pandemic, my teaching activities are performed mostly in a forum and discussion in the forms of chatting and video meeting. In my opinion, it is the most effective way to still maintain the efficacy of English learning, especially I am teaching at vocational high schools. I often use Zoom video conference and WhatsApp application." (WR. P21)

"I usually teach my students using Google classroom. There, I can post materials, checking students' attendance, and the most important we can discuss materials via comment in Google classroom. When we get bored using this website, we often use WhatsApp group to help the students learn English. Despite some problems, I think Google classroom can be used as an alternative media to conduct online teaching." (WR. P14)

Second, the results portrayed that social media not only plays role as instant messengers, but it could also be used as a medium to conduct emergency remote teaching. Most of the participants confessed that they made use several social media platforms such as WhatsApp, Instagram, and YouTube to help them run their teaching activities during the social distancing measures.

"Yes, of course I use some social media to administer my online teaching because of its practicality and ease of use. I surveyed my students' opinion about the most implementable online platform to carry out our teaching and they mostly prefer social media. Therefore, I decide to maximize the use of Whats App group as a forum of my teaching class." (Int. P11).

"I teach writing using Instagram. When I am teaching about types of English sentences, I ask my students to post a picture they like in Instagram account and provide a caption in English. Then, I ask their classmates to post suggestions and improvements in the comments. By this activity, the students are doing peer feedbacks that motivate them to improve their writings." (WR. 18)

Third, in some semi-structured interview sessions, the participants stated that designing an interesting and attractive teaching activity was a priority. The learning activities conducted online using digital platforms offer opportunities for creative teachers to design an exciting virtual classroom environment. It was revealed in this study that some participants made use of advanced platforms such as Kahoot and Quizzes as media of their teaching activities, especially in conducting exercises and games.

"Hmmm.... It is obvious that online learning gives some problems for both teachers and students. However, in conducting the online learning, I try to do my best to keep my students' motivated through an interactive activity. One of the activities is using Kahoot as a learning tool to conduct attractive online exercise and game." (Int. P3)

"After giving materials, I often administer a quiz activity to check my students" understanding, especially in grammar and reading, by using Quizzes application. It is really interesting and the students are very happy." (Int. P20) 


\subsubsection{EFL Teachers' Challenges during Emergency Remote Teaching}

Although online teaching activities could be conducted using several digital platforms, the participants' responses from self-written reflection and semi-structured interview showed that they encountered a number of challenges. First, some participants confessed that, at the beginning of online teaching administration, they had not been familiar yet to the use online learning platforms. For some teachers, conducting an online teaching was a new experience since they used to have face-to-face classroom interactions before the global pandemic, particularly in the context of teaching English for secondary level. Hence, they were required to hardly adapt to the current situation of online teaching and learning.

"When the government establishes online learning policy, the only way that crosses in my mind is to run my online teaching using WhatsApp because I am not familiar to other media. However, after having discussion and practices with my colleagues I try to use other media such as Google classroom and Zoom conference." (WR. P27)

"Yesss... at the beginning I feel hesitate how to carry out my online teaching activities with the students because I rarely use online learning tools. " (Int. P19)

Second, during the online teaching activities, the participants stated that they could not provide quick feedbacks and responses to the students. As revealed in self-written reflection and semi-structured interview, the possible reasons of the inability were the choice of digital platforms and limited internet access. Although using a video conference such as Zoom, Microsoft Team, and Google meets, the participants mentioned that it was difficult to directly provide feedbacks and responses to the students' works or questions as in face-to-face instructions. Poor internet connection possessed by both teachers and students overwhelmed the situation of emergency remote teaching during the Covid-19 pandemic.

"I face problem in giving feedbacks to my students during the online teaching, especially when the teaching and learning is using online chatting like WhatsApp or Google classroom." (WR. P1)

"One of my problems in this online teaching is inability to give fast responses to my students' works and projects. I should deal with the complexity of teaching online using digital devices and of course it needs more time. Consequently, I hardly respond to my students works." (WR. P4)

"Lack of internet connectivity prevents me to give fast feedbacks and responses for my students' questions or comments during online teaching, even I already use video conference. Also, it seems that the students do not have high motivation to join online teaching. May be, I have to design more interesting online teaching activities although for me it is very difficult." (WR. P8)

Third, lack of students' engagement and motivation to follow the online learning instructions was mentioned by the participants as the other challenge. Through self-written reflection and semi-structured interview, they stated that the students were less motivated during the online teaching. It was indicated by their limited involvement in the teaching activities, slow 
responses to the teacher's instructions, and slight number of class attendance. According to the participants, it was due to the ineffective online classroom design and the students' unfamiliarity with digital learning activities.

"In my opinion, the challenge of this online teaching is that the students seem to have less motivation and engagement. I do not know what exactly cause it, but it may because they do not familiar with online learning tools and online teaching activity itself." (WR. P6)

“.... and about the students' motivation and engagement, I find my students are not actively involved in the teaching activities. For me, it is as what I predict when we should conduct online learning. It may because the classroom activities are boring so that they are not motivated. (Int. P19)

"Yaaaahh.... I do not know why my students are not active, have slow responses to my instructions, and rarely come to the online class. I try to investigate and I find that poor internet connection and bored activities have resulted in the students' lack of motivation and engagement in my online class. It should be solved immediately.” (Int. P13).

\subsubsection{EFL Teachers' Insights and Suggestions of Emergency Remote Teaching}

Following the online teaching activities and challenges, the participants further provided alternative insights and suggestions to overcome the challenges encountered by both teachers and students during the emergency remote teaching. In relation to the unfamiliarity with the use of digital platforms, the participants suggested that trainings and development programs in digital learning practices should be extensively conducted for both teachers and students. It was obviously related to school authorities to establish such a policy. However, some participants mentioned that there were a lot of training and development programs in the forms of online seminars that the teachers and students could join freely. Hence, it would be a promising alternative to deal with the issue of unfamiliarity with digital learning platforms.

"For me, the possible solution to solve the problem about digital tools in online learning is by involving the teachers and students, especially teachers, in some trainings, workshops or seminars discussing about how to conduct an effective online learning. It is to make them be familiar with the various online learning tools and enable the teachers to design an interesting online teaching activity." (WR. P9)

"...... and the solution is creating development programs such as workshops and trainings for teachers especially to provide them ideas about designing interactive online learning activities." (Int. P25)

With regards to the teachers' inability to provide quick feedbacks and responses to the students' works, projects, or questions, the participants mentioned that teachers must control their time management and follow the lesson plan. Only by doing this, they could manage their time for teaching and provide sufficient feedbacks to each student's question or work. They also advised that teachers should design a good lesson plan and strictly follow it during the online teaching. In addition, teachers could make use of some applications and internet sites to assist them in giving instant feedbacks for the students' works such as the use of Google forms, Kahoot, and Quizzes. 
The participants believed that it could help teachers to provide quick and accurate feedbacks for students.

".... by the way to solve that problem, I think teachers must have strictly followed the lesson plan that has been previously designed. Also, time management is crucial while performing online teaching." (Int. P20)

"Yes of course. A way that can be done by teachers is giving classwork and projects to the students by using technological applications and tools such as Kahoot, Quizzes and Google forms. Hmmm... These tools will help teachers to give fast feedbacks when giving homework or projects for the students." (Int. P11).

Moreover, to solve the problem of lack of students' motivation and engagement, the participants suggested that teachers should design interactive online classroom activities so that the students are highly motivated. It would surely enhanced students' motivation and engagement to involve in the process of online teaching and learning. As depicted in self-written reflection and semi-structured interview, the most possible way to foster the students' learning engagement is by designing interesting, interactive, and innovative teaching activities. Several participants mentioned online game, interactive quizzes, and integrating music and film as alternative media to get students actively involved in the online teaching activities.

'I think to improve the students' motivation in online learning is by using interactive tools and creating interesting activities such as games and quizzes. We have Kahoot and Quizzes that can be used to get the students more motivated." (WR. 12)

"...... and it [online teaching] is such a dilemma. Therefore, designing interactive communication in online learning is a must. There is no way to enhance students ' motivation and engagement without offering them interesting activities." (Int. P25)

"I suggest that we as teachers can integrate music and film into our online teaching so that the students will not easily get bored, especially in teaching English skills such as listening, speaking, and writing." (WR. P26)

\subsection{Discussion}

In general, the present study reveals a variety of online teaching activities, several challenges, and alternative solution offered by Indonesian EFL teachers during the implementation of the emergency remote teaching. Online forum and discussion are more preferred by the teachers to conduct the online teaching activities. They utilize digital learning platforms ranging from Messenger Applications, Learning Management System to Video Conferences to facilitate the online forum and discussion. This finding confirms the results of previous studies conducted by Agormedah et al. (2020) and Amin and Sundari (2020) that online teaching and learning is highly possible to be conducted using available digital platforms and learning management systems. Moreover, this study further depicts that the use of social media is found to be an instant alternative to carry out interactive online learning. This result is consistent with what have been portrayed by Alberth et al. (2018) and Nugroho and Atmojo (2020) that informal digital learning of English 
beyond classroom could be conducted with the presence of social media such as WhatsApp, YouTube, Instagram, and Facebook.

Most of the teachers consider that unfamiliarity with the use of digital learning platforms becomes one of the challenges of the online teaching. This finding is verified by other studies that the majority of teachers slightly acquire the ability and knowledge of online learning and digital platforms (Adedoyin \& Soykan, 2020; Dhawan, 2020). The possible reason for the unfamiliarity is that most teachers, especially in Indonesia, are used to have face-to-face classroom interactions instead of online learning by means of digital platforms (Putri et al., 2020). In addition, this study depicts that inability to provide quick responses and lack of students' engagement become the other challenges encountered by the teachers. This results agree with the findings of Friedman (2020) and Toquero (2020) that English teachers must deal with the complexity of online teaching, particularly how to give teaching feedbacks and passive involvement of their students in online learning activities.

With regards to the alternative solutions to deal with the challenges, this study results in some suggestions provided by the Indonesian EFL teachers. Joining trainings and development programs to improve skills and knowledge of digital learning platforms is the most frequent recommendation for both teachers and students. Extensive involvement in such activities enables teachers to enhance their online learning capacity and equips them with the ability of designing representative teaching activities (Lailiyah \& Cahyono, 2017). This finding is in accordance with the result reported by Sithole et al. (2019) that a promising way to improve teachers' professional competence is by having them involved in trainings and development programs. This study also suggests that EFL teachers should design interactive online teaching activities to solve the problem of students' motivation and engagement. It is undeniable that lack of students' motivation is commonly caused by monotonous learning activities (Nartiningrum \& Nugroho, 2020). This result is in line with the studies of Adnan (2020) and Krishan et al. (2020) that students' engagement in learning activities highly depends on the quality of teaching instructions.

The results of this study have some implications on English language teaching. First, English teachers should begin to acknowledge that today's language learners are spending the majority of their time to engage in digital activities on their own initiatives. Thus, this study suggests that English teachers are required to evaluate their current teaching practices and to what extent they accurately reflect the needs of language learners. The global pandemic of Covid-19 is only as a 'wake-up call' to ensure that the present-day English language teaching system is ready to administer online teaching and learning (Klimova, 2019). Second, the results of this study contribute to language teachers, learners, and school administrators as fruitful insights to enhance the efficacy of online teaching and learning, particularly in the age of emergency remote teaching. The alternative solution as suggested by the participants in this study can be used as valuable inputs to deal with various challenges and problems of online teaching during the global pandemic. From a pedagogical point of view, twenty-first century language teachers have to create digital learning environments by shifting from conventional method to student-centered method, from inside 
classroom to outside classroom, and from face-to-face interaction to online learning interaction (Lai et al., 2015; Lee, 2020).

\section{Conclusion}

The in-hand study examined the voices of Indonesian EFL teachers in relation to how they carried out online teaching practices, what challenges they encountered, and alternative solution and suggestion of emergency remote teaching in the age of Covid-19 pandemic. This study leads to several compelling results. First, the Indonesian EFL teachers carried out their online teaching by administering online forum discussion using various digital platforms (e.g. Video Conferences, LMS, and Messenger Applications), integrating social media (e.g. WhatsApp, Facebook, YouTube, and Instagram), and creating interactive online exercises using Kahoot and Quizzes. Second, unfamiliarity with digital learning platforms, inability to provide quick responses to the students, and lack of students' engagement became the main challenges encountered by the teachers during the implementation of emergency remote teaching. Third, to deal with the challenges, the teachers are strongly suggested to extensively participate in development programs and trainings, create representative lesson plan for online teaching, and design interactive online teaching activities.

Nonetheless, the present study should be evaluated in regards to some limitations. First, the participants of this study are limited only to Indonesian secondary EFL teachers with different level of education and sociocultural backgrounds. Therefore, future studies in similar area should be conducted by performing a variety of data instruments (e.g. observation and survey) in order to depict more detailed data to substantiate the results of this study. Second, to enrich the data and avoid subjective opinions, future studies are encouraged to consider additional data sources such as observation, focus group discussion, and field notes to elicit the most reliable data and accurately portray the nuances of the present inquiry.

\section{References}

Abdulkareem, T. A., \& Eidan, S. M. (2020). Online learning for higher education continuity (during COVID-19 Pandemic): The challenges, advantages, disadvantages and how to overcome: A literature review. International Journal of Youth Economy, 4(2), 125-131. https://doi.org/10.18576/ijye/040206

Adedoyin, O. B., \& Soykan, E. (2020). Covid-19 pandemic and online learning: the challenges and opportunities. Interactive Learning Environments, 43(4), 1-13. https://doi.org/10.1080/02619768.2020.1821184

Adnan, M. (2020). Online learning amid the COVID-19 pandemic: Students perspectives. Journal of Pedagogical Research, 1(2), 45-51. https://doi.org/10.33902/jpsp.2020261309

Agormedah, E. K., Adu Henaku, E., Ayite, D. M. K., \& Apori Ansah, E. (2020). Online learning in higher education during COVID-19 Pandemic: A case of Ghana. Journal of Educational Technology and Online Learning, 3(3), 183-210. https://doi.org/10.31681/jetol.726441

Alberth, Mursalim, Siam, Suardika, I. K., \& Ino, L. (2018). Social media as a conduit for teacher professional development in the digital era: Myths, promises or realities? Teflin Journal, 
29(2), 293-306. https://doi.org/10.15639/teflinjournal.v29i2/293-306

Amin, F. M., \& Sundari, H. (2020). EFL students' preferences on digital platforms during emergency remote teaching: Video conference, LMS, or messenger application? Studies in English Language and Education, 7(2), 362-378. https://doi.org/10.24815/siele.v7i2.16929

Atmojo, A. E. P., \& Nugroho, A. (2020). EFL classes must go online! teaching activities and challenges during COVID-19 pandemic in Indonesia. Register Journal, 13(1), 49-76. https://doi.org/10.18326/rgt.v13i1.49-76

Barkhuizen, G. (2014). Revisiting narrative frames: An instrument for investigating language teaching and learning. System, 47, 12-27. https://doi.org/10.1016/j.system.2014.09.014

Chun, D., Smith, B., \& Kern, R. (2016). Technology in language use, language teaching, and language learning. Modern Language Journal, 100(1), 64-80. https://doi.org/10.1111/modl.12302

Creswel, J. W. (2009). Research design: Qualitative, quantitative, and mixed methods approaches. Los Angeles: University of Nebraska-Lincoln.

Dhawan, S. (2020). Online learning: A panacea in the time of COVID-19 crisis. Journal of Educational Technology Systems, 49(1), 5-22. https://doi.org/10.1177/0047239520934018

Dörnyei, Z. (2014). Researching complex dynamic systems: 'Retrodictive qualitative modelling' in the language classroom. Language Teaching, 47(1), 80-91.

Friedman, C. (2020). Students' major online learning challenges amid the COVID-19 pandemi c. J. Pedagog. Sociol. Psychol, 1(1), 45-52.

Harding, J. (2018). Qualitative data analysis: From start to finish. SAGE Publications Limited.

Hembrough, T., \& Jordan, J. (2020). Creating a digital writing classroom: A mixed methods study about a first-year composition tablet initiative. International Journal of Instruction, 13(2), 567-586. https://doi.org/10.29333/iji.2020.13239a

Hollweck, T. (2015). Robert K. Yin.(2014). Case study research design and methods. Thousand Oaks, CA: Sage. Canadian Journal of Program Evaluation, 30(1), 282 pages.

Ivone, F. M., Jacobs, G. M., \& Renandya, W. A. (2020). Far apart, yet close together: Cooperative learning in online education. Studies in English Language and Education, 7(2), 271-289. https://doi.org/10.24815/siele.v7i2.17285

Klimova, B. (2019). Impact of mobile learning on students' achievement results. Education Sciences, 9(2), 90. https://doi.org/10.3390/educsci9020090

Krishan, I. A., Ching, H. S., Ramalingam, S., Maruthai, E., Kandasamy, P., Mello, G. De, Munian, S., \& Ling, W. W. (2020). Challenges of Learning English in 21st Century: Online vs. Traditional During Covid-19. Malaysian Journal of Social Sciences and Humanities (MJSSH), 5(9), 1-15. https://doi.org/10.47405/mjssh.v5i9.494

Lai, C., Zhu, W., \& Gong, G. (2015). Understanding the quality of out-of-class English learning. TESOL Quarterly, 49(2), 278-308. https://doi.org/10.1002/tesq.171

Lailiyah, M., \& Cahyono, B. Y. (2017). Indonesian EFL Teachers' Self-Efficacy towards Technology Integration (SETI) and Their Use of Technology in EFL Teaching. Studies in English Language Teaching, 5(2), 344-357. https://doi.org/10.22158/selt.v5n2p344 
Lam, Y. W., Hew, K. F., \& Chiu, K. F. (2018). Improving argumentative writing : Effects of a blended learning approach and gamification. Language Learning and Technology, 22(1), 97118. https://dx.doi.org/10125/44583

Lee, J. S. (2020). Informal digital learning of English and strategic competence for cross-cultural communication: Perception of varieties of English as a mediator. ReCALL, 32(1), 47-62. https://doi.org/10.1017/S0958344019000181

Mutiaraningrum, I., \& Nugroho, A. (2020). Social construction of knowledge in synchronous textbased discussion during English language learning. Journal on English as a Foreign Language, 10(2), 315-336. https://doi.org/10.23971/jefl.v10i2.1934

Nartiningrum, N., \& Nugroho, A. (2020). Developing english teaching materials for accounting students: an esp approach. PROJECT (Professional Journal of English Education), 3(4), 434442. https://doi.org/10.22460/project.v3i4.p434-442

Nugroho, A. \& Mutiaraningrum, I. (2020). EFL teachers' beliefs and practices about digital learning of English. Edulite: Journal of English Education, Literature, and Culture, 5(2), 304-321. https://doi.org/ 10.30659/e.5.2.287-303

Nugroho, A., \& Atmojo, A. E. P. (2020). Digital learning of English beyond classroom: EFL learners'perception and teaching activities. JEELS (Journal of English Education and Linguistics Studies), 7(2), 219-243. https://doi.org/ 10.30762/jeels.v7i2.1993

Putri, R. S., Purwanto, A., Pramono, R., Asbari, M., Wijayanti, L. M., \& Hyun, C. C. (2020). Impact of the COVID-19 pandemic on online home learning: An explorative study of primary schools in Indonesia. International Journal of Advanced Science and Technology, 29(5), 4809-4818.

Reluga, T. C. (2010). Game theory of social distancing in response to an epidemic. PLoS Computational Biology, 6(5), 1-9. https://doi.org/10.1371/journal.pcbi.1000793

Satar, H. M. (2018). Pre-service EFL teachers ' online participation, interaction, and social presence. Language Learning \& Technology, 22(1), 157-183. https//dx.doi.org/10125/44586

Sithole, A., Mupinga, D. M., Kibirige, J. S., Manyanga, F., \& Bucklein, B. K. (2019). Expectations, challenges and suggestions for faculty teaching online courses in higher education. International Journal of Online Pedagogy and Course Design (IJOPCD), 9(1), 62-77. https://doi.org/ 10.4018/IJOPCD.2019010105

Toquero, C. M. (2020). Challenges and opportunities for higher education amid the COVID-19 Pandemic: The Philippine Context. Pedagogical Research, 5(4). em0063. https://doi.org/10.29333/pr/7947

Yin, R. K. (2015). Qualitative research from start to finish. Guilford publications.

\section{Appendix}

Questions in written reflection:

1. How do you conduct English online teaching during the emergency remote learning? What online learning platforms do you use? 
2. In your beliefs, what are advantages and disadvantages of the current situation, i.e. emergency remote teaching?

3. What challenges do you encounter amidst the emergency remote teaching?

4. What solutions and/or suggestions do you offer to overcome the challenges of emergency remote teaching?

5. What supports (e.g. school curriculum, professional development, learning materials, learning policies, etc.) do you need to enhance the efficacy of the emergency remote learning? 